\title{
The Lack of Afterlife and Its Effects on Chinese Economic Behavior
}

\author{
ZHANG Qing-jin \\ Shandong Academy of Social Sciences, Jinan, China
}

\begin{abstract}
It is widely recognized that each culture has a specific effect on the economic development. Based on Chinese culture which can be characterized as lack of afterlife, the pattern of Chinese economic development has distinctive features relative to the economy of the Western world, even to that of Japan and Korea. This paper argues that culture influences economic development through two paths: One is that some cultural factors, as certain institutions, have effects on cost, especially transaction costs. Another point is that culture forms people's preferences and influences people's choices. With the influences of Chinese culture, Chinese have a weak sense for legal obedience and strong inclination for "free riding", this would increase social transaction costs. The family centered tradition of Chinese society results in Chinese features such as being good at individual struggles but poor at cooperation, the alienation between civil society and government, a strong sense for competition and a weak sense for legal obedience, seeing material wealth as important and neglecting scientific innovation. Traditional Chinese culture also has effects on the developmental pattern of Chinese enterprises.
\end{abstract}

Keywords: utility of afterlife, transaction costs, family firm, trust

\section{Introduction}

What is the relationship between economic performance and its cultural background? It is not easy to give a definite answer, for many cultural factors are very intricate and unmeasurable, even though this relationship can be felt. However, this problem has been probed by many scholars.

The earliest investigation of the relationship between culture and economic performance may be Weber's The Protestant Ethic and The Spirit of Capitalism (1961), which ascribes the formation of capitalist society to Protestant ethics ${ }^{1}$. Following this work, the relationship between religion and economic development received substantial attention in the literature. The study of the economics of religion was thus born (for a review on economics of religion, see Iannaccone (1998). Recent literature includes Kuran (2004a), who ascribed the underdevelopment of the Middle East to some elements of Islam, such as inheritance law, avoidance of interest, and the deficient perception on corporations; Guiso, Sapienza, and Zingales (2003) compared the economic attitudes of different religions (Catholic, Protestant, Jew, Muslin, Hindu, and

\footnotetext{
* The author would like to thank Curtis Andresen for his help in perfecting the paper and improving language and YANG De-xin for his suggestions in improving some ideas.

ZHANG Qing-jin, professor, Institute of Economics, Shandong Academy of Social Sciences.

${ }^{1}$ Weber also shows the economic significance of Chinese culture, see Weber (1995), Confucianism and Taoism, p. 289.
} 
Buddhist) towards cooperation, the government, working women, legal rules, thriftiness, and the market economy, but they do not include Confucianism in their analysis; Lipford and Tollison (2002) studied the relationship between religious participation and income level and argued that there are two kinds of treasure: "treasure in heaven" and "treasure on earth".

The relationship between culture and economic development is also probed in the literature. Berger (2002) agreed with Weber and admited that there is a crucial link between culture and the economy. Guiso, Sapienza, and Zingales (2006) argued that culture has effects on economic growth through its influence on people's preference and beliefs. Greif (1994) believed that cultural beliefs are significant for the formation of different social organizations and for the distinction of different trajectories of institutional structure in the Muslim world and Latin world. Kuran (2004b) thought that culture plays a role in economic development, even if the roles are different in different environment. Greif and Tabellini (2010) examined the different historical developing paths between China and West with the distinct patterns of culture and institutions arrangement and shows the significance of culture and institutions.

Literature on new institutional economics should not be ignored in studying the relationship between culture and economic development, for the concept of culture and the definition of institution is quite similar ${ }^{2}$ (North, 1994b; Guiso et al., 2006). North (1994a) investigated the link between ideology and economic performance. He showed that a good ideology can reduce "free riding" and thus decrease transaction costs. Chueng (2002) believed that there is a link between economic performance and its environment; he also tried to connect western Christianity and Chinese filial piety with the concept of transaction costs. Obviously, the concept of transaction costs is useful in studying the economic effects of culture.

Q. J. ZHANG (2006) believed that institutions can be classified into two kinds: institutions based on strong preference and those on weak preference. Strong/weak preference is defined as the preference closely/less related with competition efficiency. As the concept of culture is similar to the concept of institutions in economics, we can also sort the cultural components into two parts: one part is the cultural components having (significant) effects on economic development and the other part, having little effect on economic development.

There has been a continuous reflection on traditional Chinese culture among Chinese intellectuals since western culture invaded China. LIANG Qi-chao criticized the Chinese personality as being servile, hypocritical, selfish, and timid, and he regarded these collective blemishes of the Chinese personality as fundamentally responsible for the weakness and poverty of the country (Y. LEI, 2006). LIANG (1990a, 1990b) and Y. T. LIN (2000) had a similar argument with LIANG Qi-chao, LIANG (1990b, pp. 38-43) believed that the features of Chinese economic development is formed by Chinese culture. The rural reconstruction done by YAN Yang-chu in Dingxian, Hebei, which is aimed to cure the main chronic illness of Chinese "ignorance, poverty, weakness, and selfishness" (Y. CAO \& N. XU, 2006). However, none of them articulate the direct link between traditional Chinese culture and Chinese economic performance. Recently, some analysis of Chinese culture has been done by economists like LIN Yi-fu and WEI Sen. For example, Y.

\footnotetext{
${ }^{2}$ North (1994b) classified institutions as formal rules and informal constraints. Formal rules include political rules, economic rules, and contracts; informal constraints include conventions, norms, and codes of conduct. See North, "Privatization, incentives and economic performance". Retrieved from http://econwpa.wustl.edu:8089/eps/eh/papers/9411/9411002.pdf. Guiso et al. (2006) defined the concept of culture as "those customary beliefs and values that ethnic, religious, and social groups transmit fairly unchanged from generation to generation", see Guiso et al (2006).
} 
F. LIN (2003) admited that there are some factors among the components of Chinese culture that hinder economic growth. But he insisted that economic growth is dominant relative to culture and cultural progress could be achieved with economic growth. However, he neglected the argument that cultural progress is relatively slow, and existing culture has effects on economic growth, either positive or negative. He also failed to show which cultural factors need improvement. With the comparison of the trajectory of institutional change between the Western world and China, S. WEI (2005) believed that China stagnated in conventional society and failed to evolve into a modern society characterized by legal constitutionalization. But he also lacked detailed articulation on the link between Chinese economic growth and cultural factors. Interesting enough, the relationship between traditional Chinese culture and Chinese economic performance receives attention from entrepreneurs. LI Dong-sheng, the chairman of TCL Group, believed that the phenomenon that the integration of Chinese enterprises is not as good as foreign enterprises can be traced as far as to the Chinese culture (J. DENG, 2006, p. C22).

The pattern of Chinese economic development has distinctive features relative to the economy of the western world, even to that of Japan and Korea. For example, most successful Chinese firms are family based; the path of economic reform taken by China is very different from that taken by Russia and other eastern European countries. China is a country with a long history and unique culture, and Chinese have unique behavior; these have been widely recognized ${ }^{3}$. But systematic and theoretical analysis is still in short supply. For example, almost everyone knows that Chinese are good at struggling individually and poor at cooperative actions, but there is no analysis to show these effects on economic growth.

This paper intends to interpret some important phenomena of Chinese firms and Chinese economic development by discussing some important features of traditional Chinese culture which have a significant influence on economic growth. This paper argues that culture influences economic development through two paths: One is that some cultural factors, as certain institutions, have effects on cost, especially transaction costs. A good institution within a firm could directly reduce production costs, and a good ideology could decrease "free riding" incentives and thus reduce social transaction costs. Chinese have a weak sense for legal obedience and strong inclination for "free riding"; this would increase social transaction costs. Another point is that culture forms people's preferences and influences people's choices. For example, the broad economic success of east Asia is partly a result of people's strong preference for saving; the family centered tradition of Chinese society results in Chinese features such as being good at individual struggles but poor at cooperation, the alienation between civil society and government, a strong sense for competition and a weak sense for legal obedience, and seeing material wealth as important and neglecting scientific innovation.

The structure of this paper is as follows: The second part sets out the main features of traditional Chinese culture which have economic significance; the third part analyzes these features with respect to economic ideas; the fourth part shows Chinese preference in economic behavior; and the fifth, the distinctive features of Chinese firms. The last part is the conclusions.

\footnotetext{
${ }^{3}$ For example, there are many articles appearing in Readers, which may be the most popular magazine in China, to discuss or criticize Chinese behaviors. Among them, see XING Zhu's “Another National Condition" (2005); LIU Su-ling's "Our Credit World" (2005); ZHANG Jie-hai's "Why You Are So Indifferent" (2005); ZHANG Jie-hai's "How Far Is the Distance Between Us and Developing Countries" (2006); and ZHANG Jie-hai's "Unserious and too Clever" (2006).
} 


\section{The Main Features of Traditional Chinese Culture}

To discuss Chinese culture, we need to distinguish two different parts: elite culture and mass culture. The difference of these two parts can be seen from the following examples: first, god and ghost exist in mass culture, but not in elite culture; second, although "loyalty" and "filial piety" are regarded as the core of Chinese culture, but "loyalty" has significance only in elite culture, not in mass culture. Filial piety is the only core value of the latter ${ }^{4}$. Because the mass is the main body of economic activities, the more relevant content here is mass culture.

To articulate the features of traditional Chinese culture, comparison of culture between China and other countries is unavoidable. From the idea of "Zhong Ti Xi Yong" (Chinese culture is the core and western culture is technique) to the combating tradition (Z. H. LI, 1994, pp. 311-341) in the May Fourth Movement in 1919 , and then to the recent "popularity of national culture studies" (Guoxue Re) ${ }^{5}$, the comparison between Chinese culture and Western culture has never stopped in modern times. Though we have no clear answer about which is better between the two kinds of cultures, but the difference and the gap between China and Western countries can not be ignored, and the effects of cultural difference on different economic patterns should not be denied. As the first step, we want to show the main features of Chinese culture, which have influenced the economic development of China.

\section{Ethics Centered on Blood Relationships and the Weakness of Socialization}

No one would disagree that traditional Chinese culture is centered on the ethics of blood relationships whose core is the family. LIANG (1990b, p. 193) believed that the difference between Chinese culture and Western culture is as that Western culture is a social one and Chinese culture values nothing except family and clan, and it is religion that results in this difference, for religion has the function of keeping people coherent (LIANG, 1990a, pp. 76-77). But in China, because of the lack of a dominant religion and the lack of group life, family becomes the center of Chinese social life (LIANG, 1990b, p. 20). Y. T. LIN (2000, pp. 29, 148, 151) also had a brilliant exposition on the lack of socialization. Nakamura (1990, p. 223) showed that the only difference between Chinese altruism and altruism in other nations is that, for Chinese, the awareness of being a member of a state or a nation is very weak. Z. H. LI (1994, p. 297) believed that the most important social foundation of Chinese ancient ideological tradition is the strong power and long continuity of the patriarchal clan system and blood relationships.

Chinese culture is centered on the family. This is the conclusion not only coming from the comparison to Western culture, but also to Japanese culture. L. P. ZHANG (1993, pp. 22-23) argued that the concept of the Chinese family contains of three levels: family, clan, and patriarchal clan, and they are combined together by blood relationships. But one character of Japanese family system is the weakness of blood relationships. He argued that while "Chinese family is an association of blood relationship, Japanese 'family' is an 'institute' with some characteristics of a financial group" (p. 27). The family is a group that is operated by different generations

\footnotetext{
${ }^{4}$ As for the difference of the core value between elite culture and mass culture, see ZHANG Lv-ping (1993), The Confliction and Integration of Civilizations: Studies of Japanese Modernization, p. 43.

${ }_{5}$ It is regarded that the sign of the popularity of national culture studies is that such institute or class were established separately in Beijing and Qinghua University. See ZHANG Yi-xuan (2005, December 15), "National Culture Studies is Popular in Chinese (Guo Ren Xingqi Guoxue Re)", People’s Daily (Overseas Edition), p. 2.
} 
in an industry. It offers services for payment. It is like a company. Therefore, we could say that Japanese family is an epitome of the organizational structure of Japanese society.

From the above, we can know that valuing family only is a unique feature of traditional Chinese culture.

\section{The Local Autonomy of Traditional Chinese Society}

Conforming with family centered Chinese ideology, traditional Chinese culture was strongly autonomous. LIANG (1990b) argued that, in China, different from the Western countries in which people used to ask help from the government when facing difficulties like unemployment, the sustaining of the social order and the operating of society depend on society itself rather than the state (pp. 72,84), the communication between the civil society and the government is very sparse (p. 158). He believed that in traditional Chinese society, there was only the idea of the world, no idea of state. Weber (1995, pp. 145-150) also argued that traditional Chinese society is autonomous.

Historically, the economic function of Chinese governments was confined to keeping the market order and monopolizing some profitable or significant industries, like salt and iron (DING, 2001; Y. B. DENG, 2003, 1999). The economic role of the Chinese government is something similar to that promoted by liberal economists.

In fact, governmental power extended only to the county level in traditional China; its main function was for tax collection and juridical judgment. Even for criminal cases, the government would not intervene without lawsuits. Civil affairs were completely autonomous (S. WEI, 2005). LIANG Qi-chao described the autonomous situation in his hometown as the following: with the autonomy in countryside, lawsuits rarely happen; people have almost no communication with local government (LIANG, 1990, p. 73; TONG, 1999). Duara's (2004, p. 2) research showed that, until Yihetuan Movement was repressed, the government of the QING Dynasty began to extend its power to the township level so as to levy more tax to pay huge indemnities.

The interesting thing is that, up to now, local autonomy is still effective in some rural areas in China. According to a report in the Legal Report Daily, a TV program from CCTV, ZHOU Yu-zhong, a farmer in Guangxi Autonomous Region, was accused of sexual harassment by a woman. He had to accept a "clan punishment" decided by elders of his village rather than a legal punishment ${ }^{6}$. Another case from the Southern Weekly (Nanfang Zhoumo) shows the same story: When reporter asked a man named LI Ping, whose daughter was beaten and killed in primary school, whether or not he would ask for help from the policeman, LI replied that people used to seek help from Elders Association in his village when having difficulties (Y. W. CAO, 2005, p. B09).

\section{Lack of Afterlife and Utilitarianism}

Weber (1995, p. 280) regarded Confucianism to be the most secular ethics in the world. About the way of thinking, Nakamura (1990) believed that Chinese nationality is usually based on the thinking way of generally known utilitarianism (p. 206); because Chinese only concern about the ethics and politics needed in daily life, some aspect of Chinese ideology could be called "realism" (p. 207); He also believed that Chinese people concern carnal desire and material desire more than spiritual things. Even the Buddhism, which is from India, was changed by Chinese utilitarianism after it was introduced into China (p. 209).

With cultural comparisons among China, India, and the Western world, LIANG (1989, p. 396) showed that

6 See Legal Report Daily (Jin Ri Shuo Fa), CCTV, December 9, 2005. See also the website of CCTV: http://www.cctv.com/program/lawtoday/20051212/101120.shtml. 
Chinese culture is very weak in religion and pays less attention to knowledge; almost all its philosophy is about life and secular things. Confucius had a well-known saying: "How can we understand death before we understand life". LIANG (1989, p. 248) also believed that "living" is the most important idea for Confucianism.

The lack of afterlife in Chinese culture can been seen from the following table. When asked with the question "how important is the God in your life", only $4.7 \%$ of Chinese people answer "very important" (see Table 1).

Table 1

How Importance is God in Your Life (Valid Percentage)

\begin{tabular}{|c|c|c|c|c|c|c|c|}
\hline Scale & $\begin{array}{l}\text { China (2007) } \\
(\%)\end{array}$ & $\begin{array}{l}\text { Japan (2005) } \\
(\%)\end{array}$ & $\begin{array}{l}\text { India (2006) } \\
(\%)\end{array}$ & $\begin{array}{l}\text { Thailand (2007) } \\
(\%)\end{array}$ & $\begin{array}{l}\text { Malaysia (2006) } \\
(\%)\end{array}$ & $\begin{array}{l}\text { US (2006) } \\
(\%)\end{array}$ & $\begin{array}{l}\text { Brazil (2006) } \\
(\%)\end{array}$ \\
\hline 1 & 39.5 & 13.1 & 8.7 & 0.1 & 0.8 & 5.3 & 1.0 \\
\hline 2 & 12.7 & 11.6 & & & 0.3 & 1.5 & 0.3 \\
\hline 3 & 8.2 & 10.1 & & 0.2 & 0.8 & 2.3 & 0.1 \\
\hline 4 & 3.7 & 5.1 & & 0.5 & 2.1 & 2.4 & 0.3 \\
\hline 5 & 9.4 & 10.7 & 33.9 & 4.4 & 9.5 & 5.8 & 0.9 \\
\hline 6 & 7.0 & 20.3 & & 8.0 & 12.6 & 5.6 & 1.0 \\
\hline 7 & 4.7 & 10.5 & & 22.9 & 10.2 & 4.7 & 1.5 \\
\hline 8 & 6.0 & 8.8 & & 28.8 & 13.0 & 6.9 & 3.5 \\
\hline 9 & 4.2 & 4.1 & & 16.9 & 10.3 & 7.6 & 4.3 \\
\hline 10 & 4.7 & 5.8 & 57.4 & 18.2 & 30.3 & 57.8 & 87.1 \\
\hline Mean & 3.6 & 5.0 & 7.5 & 8.0 & 8.1 & 8.2 & 9.6 \\
\hline
\end{tabular}

For Thailand, answer for scale 2 is in short; for India, answers only for scale 1, 5, and 10 are available.

Q. J. ZHANG (2005) pointed out that, while the behaviors of people in religious societies are constrained by dual utilities: afterlife utility and secular utility, Chinese people are only constrained by one kind of utility: secular utility, because there is no religious tradition in China.

\section{Economic Analysis of Traditional Chinese Culture}

LIANG (1990b, p. 52) insisted that the major difference between Chinese and Western culture is religion: Religion is really the watershed between Chinese and Western culture. Actually, religion is the watershed not only between Chinese and Western culture, but also between Chinese and all religious cultures. Therefore, only through comparison to religious cultures can we truly understand Chinese culture.

In religious societies, people have two utilities: afterlife utility and secular utility ${ }^{7}$. One needs to input in religious activities to gain afterlife utility and input in market activities to gain secular utility. We assume that time input is identical in all kinds of activities, whether they are secular or spiritual. The total resource constraint is the total amount of an individual's available time. We also assume that both secular utility and afterlife utility are a positive function of time. The reason that secular utility is a decreasing function of time input is easy to understand, for the assumption of diminishing marginal utility of income is regarded by most people as reasonable (Ng, 2004, p. 178). The decreasing marginal utility of religious input comes from the idea that

\footnotetext{
7 The two kinds of utilities were regarded as "wealth in heaven" and "wealth on earth" by Jody W. Lipford and Robert D. Tollison (2002).
} 
religious utility cannot be deposited: Utility of one worship or consecration cannot be used throughout a whole lifetime; an individual is required to participate religious activities continuously. People's utility function must therefore be the sum of afterlife utility and secular utility. But for Chinese people, no afterlife utility is meaningful, so people's total utility only consists of secular utility.

The difference of the different functions between Chinese and religious people is very important, for different utility function may result in different consumption preferences and behavior preferences. The unity of the Chinese utility function means that Chinese people value secular consumption only, and this preference can also be seen in the developing pattern of Chinese enterprises.

Since afterlife utility is spiritual, the gain of this utility is in the cost that one has to subject to some religious doctrines and moral constraints. However, Chinese people do not have such a cost. Q. J. ZHANG (2005) decomposed the values of afterlife utility and secular utility. According to Q. J. ZHANG, secular utility can be decomposed into values like material consumption, entrepreneurship, risk taking, creativity, selfishness, and incentives for committing crime; afterlife utility can be decomposed into values such as spiritual happiness, altruism, legal obedience, cooperation, and expansion. Now, one more value must be added to the afterlife utility: trust. Guiso et al. (2006) compared the degree of trust among different religions. Unfortunately, they did not include Confucianism in their analysis. The trust level in Chinese culture might be very low compared to that in other religious cultures (see the detailed discussion in the following section). Some values of afterlife utility have the effect of offsetting the negative aspects of secular utility. For example, altruism and legal obedience could decrease the inclination towards committing crime or free riding. Because of the lack of afterlife utility, we will argue that the inclination towards crime and free riding is relatively strong among Chinese.

Furthermore, when the increase of secular utility is limited by such issue as technology stagnation, the total utility of Chinese people might be less than religion believers in other societies. This was confirmed by an investigation by $\mathrm{Ng}$ (2002), who found that people in east Asia enjoy less happiness.

\section{The Behavior Preference of Chinese}

Social values in society certainly include economic attitudes. Guiso et al. (2006) compared the different economic attitudes between the different religions of Catholic, Protestant, Buddhism, Judaism, Islam, and Hinduism. It is a regret that Confucianism is less analyzed. This paper tries to make up for this omission.

Determined by the distinct features of traditional Chinese culture, such as the lack of afterlife, we believe that the distinctive economic attitudes embodied in traditional Chinese culture include the following: (1) preferring individual struggle and belittling cooperation; (2) the alienation of civil society from government; (3) ideology strong in competition but weak in institutional obedience; and (4) valuing wealth accumulation and overlooking scientific innovation. The following sector provides the details.

\section{Preferring Individual Struggle and Belittling Cooperation}

On this preference of Chinese economic attitude, B. YANG (1985, pp. 25-26), a Chinese writer, argued that if putting Chinese together, they would be as weak as a reptile, because what Chinese are good at is internal conflict. There will be internal conflict in wherever Chinese are as Chinese are always disunited; it seems that there is no unity cell in Chinese bodies. 
Nakamura (1990, pp. 222-225) believed that Chinese culture promotes inclination to egoism, and Chinese have a weak awareness of both nation and state. With the comparison between Chinese and Japanese culture, L. P. ZHANG (1993, p. 37) showed that the life-attitude and life-philosophy of Chinese is based on individualism, but that of Japanese is based on collectivism.

This feature comes from the ethics centered on blood relationships and the weakness of sociality. Just as LIANG (1990b) criticized, the lack of religion and organization is prevalent in traditional Chinese culture. Without religious faith, there is no social value beyond the family or clan. Because of the shortage of sociality and social organization, there is no custom for social cooperation in traditional Chinese society. Actually in traditional Chinese society, there is no need for social cooperation. Almost all businesses can be done by family or clan members, and all problems can be solved within the clan.

Another reason accounting for Chinese preferring individual struggle and belittling cooperation is institutional. Institutionally, the concept of social equality is very helpful for social cooperation. But this concept is very weak in traditional China. Even though the clan is a kind of organization, people could not enjoy equality within the clan. The individual's position within a clan was determined by blood relationships, which were fixed by birth. Furthermore, cooperation needs legal protection. But the legal system in traditional China was not good enough for cooperation beyond the family or clan. Traditional China is more autonomous than legally administrated. Chinese people used to trust others less, especially strangers. This was confirmed by Weber and Y. T. LIN. Y. T. LIN (2000, p. 161) said that Chinese used to treat familiar people with friendship, but used to be hostile to strangers. Weber (1995, p. 284) said that the distrust among Chinese people is visible everywhere, which is in striking contrast with Puritan's sincerity. Without a good legal administration, there was a high risk in cooperating with strangers. To reduce risk, cooperation was usually limited to local areas. A good example is that the Shanxi commercial firms that prospered in the MING and QING Dynasties only hired employees from local areas (see WANG \& Ma, 2001, especially pp. 276-280).

\section{The Alienation of Civil Society From Government}

"Loyalty" and "filial piety" are generally regarded to be the core values of Chinese culture. But actually, "being loyal to emperor" is only meaningful in elite culture, whereas in mass culture the only core value is "filial piety". "Though government always promotes 'loyalty', common people generally regard 'filial piety' to have priority, except at the time that the country was invaded by foreigners" (L. P. ZHANG, 1993, p. 43). Just for this reason, LIANG (1990b, pp. 157-188) believed that what is significant for Chinese is the concept of the world, rather than the concept of state or country. This can also be shown by the idiom: "The old

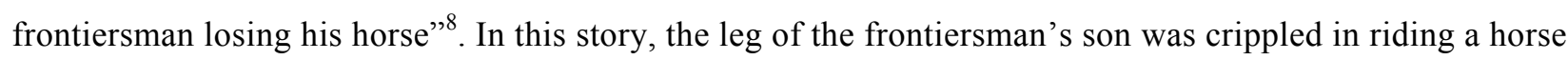
and thus the son escaped from being recruited to fight for the country, the old frontiersman thought this is a lucky thing. Obviously he did not think that he needs to take duty of "being loyal to the ruler and devoted to the country".

Why is "loyalty" meaningful in elite culture? The reason is that the elites could gain utility from "loyalty to the emperor", but the masses could gain nothing from this kind of loyalty.

\footnotetext{
${ }^{8}$ See Huai Nan Zi-Renjian Pian, in Collection of Various Schools of Thought (Zhu Zi Ji Cheng) (2006). Chinese Publishing House.
} 
Traditional Chinese government followed the principle of "governing by noninterference" (Wu Wei Er Zhi $)^{9}$, which is something similar to the minimalist government advocated by liberal economists ${ }^{10}$. Historically, Chinese government, except for monopolizing some important industries, provided only necessary public goods and services, such as excavating or dredging rivers, establishing or maintaining post stations. However, according to Duara, the public goods provided by the government amounted to very little in the period from the end of the QING Dynasty (1644-1911) to the Republic of China (1912-1949) ${ }^{11}$. The cooperation between civil society and government was rarely visible. Though, in the time of the Westernization Movement, some private firms sought protection from government with the name of "being sponsored by government and run by businessmen", but this protection was obtained at significant cost (ZHOU, 2001, pp. 112-113). Conversely, officials' work used to appear negatively in society: either to pressgang conscripts or to levy taxes, which was popularly resented. For example, Duara $(2004$, pp. 2, 32, 35, 166) found that the extension of government power to the countryside in the period from the end of QING Dynasty to the Republic of China, was aimed at increasing revenue. The officials responsible for tax levies were often resented. The countryside elite and villagers often united to resist expropriation by the government or its agents.

\section{Ideology Strong in Competition but Weak in Institutional Obedience}

Social sense is in very short supply in traditional Chinese society, just as Y. T. LIN (2000) said: "What China is short in is movements, political association, religion, which constitute social life in Britain and America" (p. 148), "for Chinese, social work is often seen as interference to others. People committing to social reformation and other public affairs seem ridiculous" (p. 150). In traditional China, people did not have experience in social movement or social activities, so the equality concept was not popular. Y. T. LIN argued that equality was often replaced by a hierarchical system ${ }^{12}$. On the other hand, Chinese society is quite open, "In China, no fixed boundary exists between different classes, no fixed nobles exist too, what exists is the rise and fall of different families, measured by the decrease and increase of family wealth" (Y. T. LIN, 2000, pp. 164-165). China had a hierarchical system but it was not fixed, so each family had an incentive to obtain a better relative standing ${ }^{13}$. The standard of relative standing for a family is determined by the level of family wealth. So there is a natural competition for a better relative standing between different families. This makes Chinese people very adaptable to competition, and the family is a natural economic unit which is good at competition.

\footnotetext{
${ }^{9}$ LU Xin-wu (in MING Dynasty) said: "The principle of governance must be: safety comes from non-disturbance, giving comes from non-expropriation, benefit comes from non-harm, non-interference means promoting beneficial things and abolishing harmful things", in Shen Yin Yu of Zhi Dao Pian (as cited in LIANG, "The Gist of Chinese Culture", Collected Works of Liang Shuming (1990a), p. 158).

${ }^{10}$ Friedman argued that the duties of government should be limited. The main task of government must be protecting people's freedom from be invaded, that is to protect legal system and order, to guarantee the performance of private contract and to assist the competitive market. See Friedman, Capitalism and Freedom (Chinese edition) (2004), p. 5.

${ }_{11}$ On the role of Township Public Department (Xiang Gong Suo), Duara said, as a bigger grass-root department, Township Public Department was expected to provide some public service, but the only achievement we can found is that a well was dug in Wu Dian Village for irrigation. See Duara, Culture, Power, and the State: Rural North China, 1900-1942 (Chinese edition) (2004), pp. 161-162.

${ }^{12}$ In traditional China, everyone got a fixed identity from the hierarchy system: Common people must be obedient to the rulers, elders must be kind to and respected by youngsters, elder brothers must treat younger brothers friendly and the younger brothers must be modest to the elder brothers, etc. See LIN, Yu-tang, My Country and My People (Chinese edition) (2000), pp. 159, 161.

${ }_{13}$ On the importance of relative standing, see Yew-kwang Ng, Welfare Economics: Toward a More Complete Analysis (2004), pp. 266-268.
} 
However, institutions were not well developed to constrain individual competition in Chinese society.

For Chinese, only when related with some individual relationships, such as the relationship between father and son, the monarch and his subjects, or husband and wife, could morality be significant, so Chinese are rarely concerned about public rules pertaining to ethics and laws which are found in other countries or societies. (Nakamura, 1990, p. 223)

It is said that the Western legal system originated from religion (Berman, 1993; Hayek, 1997, pp. 204-207). The weakness of religion in China must be responsible for the weakness of law or institutions. One of these results is that Chinese has a strong inclination for free riding. One businessman in Wenzhou, Zhejing Province, even said: "Nothing is correct or wrong in Wenzhou, the only meaningful thing is to try" (XIAO, 2005, p. C22). Another example is the poor development of Chinese credit market. According to one survey, up to the end of November, 2003, the debt default only among certain scaled enterprises (sale income above five million RMB) amounted to $1,862.4$ billion $\mathrm{RMB}^{14}$. Some debt default is on purpose, rather than a shortage of finance. For example, ZHENG Bing, a farmer in Yongji City, Shanxi Province, established a store selling fertilizer and pesticide in 1997, but up to 2000, she was defaulted by villagers to the amount of about 110,000 RMB. She also guaranteed for one farmer's loan of 150,000 RMB, but the debt fell on her because of the farmer's default. The farmer saved money in the bank, but did not pay her (MA, 2006).

The high rate of law violation among Chinese people can be shown by the following case. According to the Southern Weekly, The cases of rule violation in Russia made by Chinese people are much more than that made by other nationalities. ... In 2004, 8.66 million foreign people entered Russia and the number of cases of violating administrational rules was 104,000 , the ratio of rule violation to the total entry is 1:83. But for Chinese entering into Russia, the cases of rule violation are 32,886 , the ratio of being punished to the total entry is $1: 23$. As for the Chinese people staying Russia for more than three days, the ratio of violating administration rules to the total population is $1: 13 \ldots$ The cases that Chinese people violating Russian administration rules are higher than other nationalities ${ }^{15}$.

\section{Valuing Wealth Accumulation and Overlooking Scientific Innovation}

Chinese have a reputation for accumulating wealth, but this feature comes from the competition for better relative standing between families. Because the test measuring the relative standing is the amount of wealth, Chinese have a strong incentive in terms of wealth accumulation. Because to increase market income is the only way to increase utility, it is a natural thing that Chinese value material wealth above all. Therefore, Chinese are well known as hard working people.

Another way for wealth accumulation is to be thrifty besides working hard, so Chinese are also known to be frugal. Being hard working and thrifty are popular faith in China, a business could be established and maintained with this (LIANG, 1990b, p. 196). If a person is famous for hard work, thrift, wealth accumulation, and stinginess, it can be found that family awareness acts on him (Y. T. LIN, 2000, p. 151). Wealth accumulation is also helpful for economic development. The people's untiring pursuit of wealth is a great impetus for Chinese economic growth.

\footnotetext{
${ }^{14}$ See "Analysis on the Seriousness of Debt Default Problem Among Big Enterprises in Contemporary China", written by Investigation Group of Credit Management, Industrial Economic Association of China, cited from the Web of Global Manufacture (Quanqiu Zhizao Wang): http://law.easyeb.com/weihai.jsp.

15 Gonqialov (2006, January 5). "It is not true that Chinese population expanding in Russia", Southern Weekly (Nanfang Zhoumo). Note: Chinese people referred here may be Chinese travelers or businessmen in Russia, not Chinese residents in Russia. The difference between residents and non-residents is that the former is better adapted to the local rules than the latter.
} 
According to institutional economics, institutions play a significant role in terms of economic development. A good economic performance depends on good institutions. However, the institutions in China are far from being perfect. For example, property rights are not well specified so far, but China's economy has been growing rapidly in the past twenty years. One reason accounting for this is that the strong desire for wealth of Chinese people somewhat offsets the disadvantages of Chinese institutions.

However, Chinese people do not have a good sense in scientific innovation. Y. T. LIN (2000, pp. 71-73) ascribed the lack of scientific spirit in China to the way of thinking innate in traditional Chinese culture. LIANG (1990b, pp. 267-276) argued that Chinese culture values "human" too much and neglects "objects", and this is why science could not develop well in China. Weber (1995) thought that Chinese lack both rational thinking and technological experiment which is supported by business, thus China lacks rational sciences (pp. 201-202); they reject and even have no such knowledge as that cannot be directly useful (p. 284). Even Richard Lynn, who argued that east Asian's IQ is higher than Europeans, showed that traditional Chinese culture does not encourage innovation and even throttles new ideas or new creations, and the Chinese educational system lays more stress on existing knowledge and on the training of obedient followers, rather than original innovators (C. WEI, 2006).

\section{The Effects of Traditional Chinese Culture on Firm Management}

\section{The Popularity of Family Firms}

Family firms exist in many economies, but it is much more popular in Chinese circles than in other societies (W. LI, 2003, pp. 62-67). Anhui firms (Hui Shang), which had a long established reputation in China, based their business on family firms; and Shanxi firms (Jin Shang, they enjoy an equal historical reputation with Hui Shang), while not limiting their business within family, based their business within regions, they even only hired employees born within Shanxi (WANG \& MA, 2001, pp. 22, 94, 276-280). Almost all the successful Chinese firms in Taiwan and Hong Kang are family firms, such as WANG Yong-qing's Tai-Tsu Group, Da Hua Bank Group in Singapore, and San Lin Group in Indonesia. Seventy percent corporations in Hong Kong are family firms (Cookson, 2011). Though in different environments, overseas Chinese similarly take the same organizational pattern of firms, i.e., the family firm (D. LEI, 1993, p. 4).

Furthermore, the Chinese family firm is different from the Western family firm. From appearance, the new transnational groups run by overseas Chinese are similar to other corporations, such as their establishment: They have a board of directors and staff, but their operating style is completely different from anything else in the world economy, the best way to describe them is to see them as families operating together (Drucker, 1999, p. 157).

Almost all the private firms in Mainland China are family firms. According to one article, in the present non-publicly-owned economies in Mainland China, the ratio of family firms is no less than $90 \%$; the ratio even is higher in coastal areas like Jiangsu and Zhejiang. The article also argues that the key positions in these firms are usually occupied by family members, even if they are corporations judged by appearance and hire professional managers ${ }^{16}$. Another article insists that the only reason for private firms in Mainland China to reform is family management. The owners often distrust managers and come into conflict with managers, even if the managers are usually professional (LU, 2001).

\footnotetext{
${ }^{16}$ The article is titled "Chinese Family Firms Are Taking Mean Way", in Contemporary Finance and Economy in Xinhua Web. Retrieved from http://news.xinhuanet.com/fortune/2002-10/11/content_592716.htm.
} 
The popularity of the family firm in Chinese circles may come from the Chinese preference for individual struggle and distrust of others and thus they have bad performance in cooperating. For example, CHEN Jiu-lin, the former CEO (chief executive officer) of China Aviation Oil Holding Co., who was arrested in Singapore for illegal operations, expressed the view that Chinese overseas firms are not well integrated and thus are very weak as individuals. Japanese overseas firms tend to be well united, but Chinese firms are just like a plate of sand. When one firm faces difficulty, it could hardly seek help from other Chinese firms (HAN, 2006, p. B14).

However, family firms have special advantages in management. Because family members share common interests, they usually like to make their contribution to firm development and thus to decrease free riding behavior within the firm; family firms do not need to cost for the relationship between principal and agency; family firms can make quick decisions and change their strategies rapidly, and so on. The economic success in Chinese circles, to some degree, is gained from the advantages of family management. In particular, the economic prosperity in Mainland China since the end of the 1970s is closely related to the rapid development of family firms. However, family firms have apparent disadvantages. For example, the knowledge and capability of professional managers are used insufficiently; they suffer losses in scale economy; and they are less capable in technological innovations. The advantages and disadvantages may depend on particular industries. They may enjoy advantages in industries suited to small scale, such as service industries, and suffer disadvantages in industries good for large scale production, such as automobiles.

\section{The Alienated Relationship Between Firms and Government}

The relevant firms here are private ones; state-owned firms are too special to be included.

Undoubtedly, governments have played an important role in the economic development of east Asia, though there continues to be controversy about whether their role is positive or negative. ${ }^{17}$ However, this paper argues that governments' economic interference in Hong Kong and Taiwan played much less a role than that in Japan and Korea. Government in Mainland China is, of course, an exception.

The role played by the Japanese government in economic development is well known. Obviously, the Japanese economy is not a laissez-faire one, and the interference of the Japanese government not only changed industrial resource distribution, but also influenced the production activities of private firms (P. XU, 2003, p. 14, and footnote 2). According to L. P. ZHANG (1993), throughout the industrial revolution, Japanese government played a significant role and this is a typical feature of Japanese industrialization. ... Because of the weakness of the (Japanese) bourgeoisie, it is government, rather than the bourgeoisie who promoted Japanese industrialization (L. P. ZHANG, 1993, p. 195). The state, like a shield, carefully fostered and protected the growth of capitalism; in turn, all of the protected large financial groups and firms attached itself to state power (L. P. ZHANG, 1993, p. 196). In the modern economy, it is the Regulation of Important Industries, which was implemented in 1931 in Japan, that best reflects the role of the Japanese government, Important industries were decided by government, the choice of specific objects depended on the judgment of governmental departments, and did not need to go through legal procedures. On one hand, firms had to

\footnotetext{
${ }^{17}$ See WU Jing-lian's Chinese preface, Aoki Masahiko's English preface, Aoki Masahiko, Kevin Murdock, Okumo Masahiro, ZHAO Chen-ning, and ZHANG Lu (1998), "New Interpretation for the Government Role in Economic Development in East Asia: Market Enhancement Theory", and other papers in The Role of Government in Economic Development in East Asia, edited by Masahiko Aoki, Hyung-Ki Kim, and Masahiro Okuno-Fujiwara.
} 
operate according to the orders and supervision of government; on the other hand, they received benefits from the government such as tax exemptions and finance. After World War II, though Japan was forced by US to implement political and economic reform, many governmental functions were retained and some were even enhanced (P. XU, 2003, pp. 77-129).

While tycoons play a significant role in Korean economic life, they do so in cooperation with government. YIN (1993) insisted that, in the relationship between firms and government, government keeps authoritative power to regulate and command firms, and this is typically important to Korean economic development (YIN, 1993, p. 185). The government formed a relationship with large firms, that is, government pursued a developmental plan, and firms pursued profits. Large private firms played a major role in export oriented production, therefore they received more support from government in loans and technological imports (YIN, 1993, p. 180). The Park Chung Hee regime managed to force firms like Samsung to be consistent with state plans through investigating but not punishing those firms which accumulated wealth illegally under the Rhee Syngman regime (YIN, 1993, pp. 178-179). The habit that people's obedience to and fear of officials which was produced by Confucianist tradition helped the government to achieve its goals (YIN, 1993, p. 176). To regulate business, the Korean government not only used economic measures like taxes and loans, but also used administrative decrees. Park Chung Hee often regulated large projects himself, he chaired "the Promoting Association for Expanding Exports" once a month, ... He may be the only one in the world that stressed production directly as a President (YIN, 1993, pp. 74-75, 175-176).

Relative to Japan and Korea, the relationship between firms and government is not so close in Hong Kong and Taiwan. Hong Kong is known for its laissez-faire development (LIU, 1998). The government regulation of firms in Taiwan is not as effective as that in Japan and Korea, for the main body of Taiwan business is small and medium firms, and the monopoly of industries or products is relatively low. It is difficult for government to regulate many firms when pursuing a development plan. This can be shown by that the public sector in Taiwan is stronger than that in Japan and Korea. In the early 1950, the ratio of property value in the public sector amounted to $90 \%$ (LIU, 1998, p. 54). In 1976, the products of the public sector in Taiwan accounted for $22.1 \%$ in terms of the total product, but the products of public firms only accounted for 8.0\% in total GDP in Korea (YIN, 1993, p. 173). In the 1980s, the product ratio of the public sector was still as high as $15 \%$ (LIU, 1998, p. 54). The public sector in Taiwan covers many profitable industries such as electricity, oil, sugar, fertilizer, iron and steel, machinery, shipbuilding, building, salt and electronics, and so on, so it is very obvious that the government competes with the private sectors for profits (YIN, 1993, p. 173). From here we can see that, while governments could pursue development goals through the private sector in Japan and Korea, the Taiwanese government had to do so through the public sector. This shows that the relationship between government and private firms in Taiwan is not as close as that in Japan and Korea.

From appearance, the relationship between government and firms in Chinese circles is somewhat similar to that in Western countries where people used to be skeptical about government actions, but actually, they are very different. With the awareness that the excess of state power would be harmful to individual freedoms and civil society, effective institutions, like constitutions, were developed to limit the power of the state in Western countries. Therefore, the relationship between government and firms has been institutionalized in Western 
countries. But in Chinese societies, the institutions are so imperfect that it is a common thing that private domain is invaded by the state. As discussed above, the Taiwan government monopolized many important and profitable industries for a long time, and private firms had to keep away from these industries. The unfairness suffered by private firms is even more serious in Mainland China. With government monopolies, the private sector not only has to stay out of many important and profitable industries such as electricity, telecommunications, banking, shipping, and air transportation, but is also discriminated in tax and credit areas. For many times, the interests of private firms are not well protected by government ${ }^{18}$. Moreover, civil society cannot benefit from the social security provided by government, for the tradition that government provides social security for civil society, which is prevalent in western countries, does not work in Mainland China.

Sometimes, even state owned firms failed to seek help from government. For example, after CHEN Jiu-lin, the former CEO of China Aviation Oil Holding Co. was arrested in Singapore for illegal business operations, Han Fangming stated that:

When Americans commit crimes in Singapore, the US government pleaded with the Singapore government; Australia did the same when Australians were charged in Singapore. But when Chen Jiulin was accused by the Singapore government, the Chinese government never tried to do anything for him. (HAN, 2006, p. B14)

\section{Strong in Imitation and Weak in Innovation}

It is said that the success of Jewish business is normally based on innovation and the success of Chinese business is normally based on imitation. While we have little chance to testify if the above statement is true for Jewish people, we know that imitation is really popular in China. The main evidence is that there have been so many cases where Chinese do business akin to swarming bees. When a firm is successful in a product or with a technology, thousands of firms imitate it and eventually make the product or technology valueless. The phenomenon of "swarming bees" production occurred many times in Chinese agricultural production in the 1980s. A typical case is in haw production. When some areas made money from growing haws, many other areas learned to grow haws and finally made the haw unsalable. The same phenomenon also happened in industrial production. A typical case is the development of the television and refrigerator industries. When some firms were successful in these areas of production, such as Hisense in TV production and Haier in refrigerator, many factories were built to produce TV sets and refrigerators and almost every province had its own factories for producing these items. The consequence is that over-production of televisions and refrigerators continues even today. "Swarming bee" production has even occurred in high tech areas. Within one year after the photovoltaic industry landed in China, Chinese firms involving in photovoltaic production number no less than 30 (Z. XU, 2006, p. C23).

While the electronic industry was built up quickly in China through technological imitation, the industry is now suffering the weakness of technological innovation. For example, thanks to successful technological imitation, the Chinese television industry has become the largest one in the world. TV sets made in China enjoy

\footnotetext{
18 The property right in private firms not only could not be effectively protected by government, but also hurt directly by government. For example, in order to exaggerate the economic achievement, the administrative leaders in Lu Long County, Hebei Province, tried to change a private firm into county-state owned firm. After be refused, the county leaders arrested YAO Qing-shan, the main leader of that private firm, with a charge framed up. See Legal Report Daily (Jin Ri Shuo Fa), CCTV-1, July 10, 2003.
} 
advantages in price in competition with TV firms of advanced countries. However, for the weakness in technological innovation, the advantage enjoyed by Chinese TV firms is only limited to traditional technology. Many TV firms in developed countries have withdrawn from the production of traditional technology and turn to the production of liquid crystal TVs, which need higher technology and is more profitable. Chinese TV firms are troubled by the lack of flat panel technology and the consequence is that although $70 \% \mathrm{TV}$ sales is of Chinese national brands, $80 \%$ of profits are taken by foreign firms producing liquid crystal flat panels ${ }^{19}$. Another case is DVD production. Chinese DVD products almost monopolies the world market, but the firms producing DVDs are troubled by huge patent fees for they lack core technologies (A Survey on DVD Patent Fees, 2004). The same thing also happened in the cell phone industry. China is the biggest producer of cell phones, but Chinese firms cannot develop core technology and have to buy such technology from foreign firms (FENG, 2006, p. C24).

The weakness of Chinese firms in innovation has been noted by a number of entrepreneurs. For example, LI Dong-sheng, the Chairman of TCL Group, believed that "Chinese education lacks developing innovation capabilities, and Chinese culture does not encourage innovation” (J. DENG, 2006, p. C22). X. K. YANG (2000) made the criticism that China only pays attention to technological importation but neglects institutional imitation. Obviously, X. K. YANG is also correct for Chinese firms.

\section{Conclusions}

As a rational entity, company has a strong motivation to maximize its profits. At the first sight, the rational character will make a company give up its outdated culture and adopt a new culture that could maximize its efficiency. But, in the real world, cultural change is much slower than technological change. Because of the adoption of new technology, a company could improve its technique level overnight. But, cultural change will need unremitting effort of a whole generation or even a few generations.

At the initial stage of globalization, because of relative isolation, even for the culture that has influence on company's efficiency, there are still obvious difference among different countries. And the uniqueness of Chinese culture is proverbial. Just because of the unique characters of Chinese culture, Chinese firms show a different character from Western firms, like the popularity of family firms, the distant relationship between government and business, the recognition of imitation and the neglect of innovation, and the weakness of institutional consciousness. All of these characters have a different influence on a Chinese firm's competition efficiency. As for the family firms, although they have the advantage of small size, quick feedback, and free commission fee, when they compete with large stock companies in the world market, these family firms always show their weakness in innovation and economic power. In the Asian financial crisis in the late of the 1990s, why could the Chinese circles escape by the skin of its teeth? There is no doubt that the small size of firms and the distant relationship between government and businesses contribute to that to some extent. Although Chinese do not have enough conscious of science and innovation, according the authors opinion, a main driving force for the rapid growth of China's economy is that Chinese desire wealth. In international competition, there is also an optimizing process for the culture which has an influence on competition efficiency. So there should be the

\footnotetext{
19 This is the words of WANG Dian-fu, who is from Chuangwei, a TV firm. Here is cited from ZHANG Chun-wei's "Price Competition in Crystal Liquid TV, Local Firms Stay Aside (Yejing Dianshi Jiage Zhan, Bentu Changshang Yibian Kan" (2006, January 26), p. B15.
} 
timing adjustment of company characteristics which are determined by cultural characteristics those companies are facing. As we have seen, many family firms in Taiwan and Mainland China have been trying to adjust their operations way after they became aware of family firm's weaknesses. And although imitation of existing technology could help Chinese firms and promote China's economic development, sustainable progress in the future will only come from the improvement of Chinese firm's innovation ability.

\section{References}

A Survey on DVD Patent Fees (DVD Zhuanli Feiyong Yilan). (2004, July 16). The Market (Shichang Bao), p. 12.

Aoki, M., Murdock, K., Okumo, M., ZHAO, C. N., \& ZHANG, L. (1998). New interpretation for the government role in economic development in east Asia: Market enhancement theory. In M. Aoki, H.-K. Kim, \& M. Okuno-Fujiwara (Eds.), The role of government in economic development in east Asia. Beijing: China Economic Publishing House.

Berger, P. (2002). Introduction: The cultural dynamics of globalization. In P. Berger \& S. P. Huntington (Eds.), Many globalizations: Cultural diversity in the contemporary world (pp. 1-16). New York: Oxford University Press.

Berman, H. J. (1983). Law and revolution: The formation of the western legal tradition (Vol. 1). Cambridge, M.A.: Harvard University Press.

CAO, Y. W. (2005, December 15). A diary of a student who was beaten. Southern Weekly, p. B29.

CAO, Y., \& XU, N. (2006, March 9). One century's nostelgic: From Yan Yangchu to Wen Tiejun. Southern Weekly (Nanfang Zhoumo), p. A6.

Chueng, S. (2002). Economic explanation-selections from Steven Chueng's economic thesis (pp. 438-440). Beijing: Business Press.

Cookson, R. (2011). Investors learn how to play the generation game. Chinese Web of Financial Times. Retrieved from http://www.ftchinese.com/story/001036780/en

DENG, J. (2006, March 16). China manufacture is upgrading (Zhong Guo Zhi Zao, Su Liu Er Shang). Southern Weekly, p. C22.

DENG, Y. B. (1999). The role of state in the circulation of goods (pp. 1644-1840). Beijing Social Science, 3.

DENG, Y. B. (2003). Market policy and administration of state in early time of Qing Dynasty. Chinese Commercial History, 4.

DING, C. Q. (2001). Investigation on state intervention in market in Chinese history. Nankai Univeristy Journal (Philosophy and Social Sciences Edition), 6.

Drucker, P. (1999). Managing in a time of great change (Chinese Edition). Shanghai: Shanghai Translation Publishing House.

Duara, P. (2004). Culture, power, and the state: Rural north China, 1900-1942 (Chinese edition). Nanjing: Jiangsu People's Press.

FENG, Y. D. (2006, March 9). Flat-panel TVs repeated the failure of cell phone. Southern Weekly, p. C24.

Friedman, M. (2004). Capitalism and freedom (Chinese edition, p. 5). Beijing: The Commercial Press.

GAN, D. A. (2002). Studies of Chinese family firms. Beijing: Chinese Social Sciences Press.

Gonqialov, C. (2006, January 5). It is not true that Chinese population expanding in Russia. Southern Weekly, p. B16.

Greif A. (1994). Cultural beliefs and the organization of society: A historical and theoretical reflection on collectivist and individualist societies. Journal of Political Economy, 102(5), 912-950.

Greif, A., \& Tabellini, G. (2010). Cultural and institutional bifurcation: China and Europe compared. American Economic Review: Papers \& Proceedings, 100(2), 1-10.

Guiso, L., Sapienza, P., \& Zingales, L. (2003). People's opium? religion and economic attitude. Journal of Monetary Economics, 5, 225-282.

Guiso, L., Sapienza, P., \& Zingales, L. (2006). Does culture affect economic outcomes?. The Journal of Economic Perspective, 2, 23-48.

HAN, F. M. (2006, April 14). CAO (China Aviation Oil) event: Reflection afterward. Southern Weekly, p. B14.

Hayek, f. (1997). The constitution of liberty (Chinese edition). (Z. L. DENG Trans.). Shanghai: Joint Publishing.

Iannaccone, L. R. (1998). Introduction to the economics religion. Journal of Economic Literature, 36, 1465-1495.

Kuran, T. (2004a). Why the middle east is economically underdeveloped: Historical mechanisms of institutional stagnation. Journal of Economic Perspectives, 18, 71-90.

Kuran, T. (2004b). Cultural obstacles to economic development: Often overstated, usually transitory. In V. Rao \& M. Walton (Eds.), Culture and public action (pp. 115-137). Stanford: Stanford University Press.

LEI, D. (1993). The management thought of overseas Chinese entrepreneurs: The cultural background and style. Shanghai: Joint Publishing. 
LEI, Y. (2006, March 9). The nationality in the view of Chu Anping. Southern Weekly, p. D30.

LI, W. (2003). The social changes in the east Asia. Beijing: World Knowledge Press.

LI, Z. H. (1994). On the history of Chinese ancient thoughts. Hefei: Anhui Wenyi Press.

LIANG, S. M. (1989). Collected works of Liang Shuming (Vol. 1, pp. 321-539). Jinan: Shandong Renming Press.

LIANG, S. M. (1990a). Collected works of Liang Shuming (Vol. 2, pp. 141-586), Jinan: Shandong Renming Press.

LIANG, S. M. (1990b). Collected works of Liang Shuming (Vol. 2, pp. 1-316), Jinan: Shandong Renming Press.

LIN, Y. F. (2003). Economic development and Chinese culture. Human civilization towards future: Multi-disciplinary studies-collection of 2nd Beijing University forum. Beijing: Beijing University Press.

LIN, Y. T. (2000). My country and my people. Changsha: Yuelu Press.

Lipford, J. W., \& Tollison, R. D. (2002). Religious participation and income. Journal of Economic Behavior \& Organization, 51, 249-260

LIU, Z. Y. (1998). The role of government in economic development: Investigation in Chinese mainland, Hong Kong and Taiwan. The role of government in economic development in east Asia. Beijing: China Economic Press.

LU, N. (2001). Three puzzles in the reformation of private firms. Sina Web. Retrieved from: http://finance.sina.com.cn/d/20011119/139314.html

MA, C. B. (2006, March 9). Zheng Bing: Returning from farmers association. Southern Weekly, p. A4.

Nakamura, H. (1990). Ways of thinking of eastern people (Chinese edition, pp. 150-155, 206-216). Taipei: Shuxin Publishing House.

Ng, Y.-k. (2002). Where will China go? The cultural difference between West and East and the revelation of recent literature. Living environment and Chinese culture under new economic conditions. Hangzhou: Zhejiang University Press.

Ng, Y.-k. (2004). Welfare economics: Toward a more complete analysis. London: Palgrave Macmillan.

North, D. C. (1994a). Structure and change in economic history (Chinese edition, pp. 49-65). Shanghai: Shanghai Sanlian Press and Shanghai Renmin Press.

North, D. C. (1994b). Privatization, incentives and economic performance. Economic History (9411002). EconWPA.

TONG, X. G. (1999). Studies of Xiang Li system in ancient China. Jinan: Shandong Renmin Press.

WANG, K., \& MA, X. Y. (2001). Anhui firms and Shanxi firms (Hui Shang Yu Jin Shang). Beijing: Arms Industry Press.

Weber, M. (1961). The protestant ethic and the spirit of capitalism. Routledge: Chapman \& Hall.

Weber, M. (1995). Confucianism and Taoism. Beijing: Business Press.

WEI, C. (2006). The IQ of Chinese people leads in the world. Chinese Times, 8 . Retrieved from http://www.ftchinese.com/sc/story.jsp?id=001003808\&loc=DAILY\%20EMAIL

WEI, G. Q. (2005). A historical thinking of county system in modern times. Reading (Bo Lan Qun Shu), 10.

WEI, S. (2005). Studying the constitutionalization process of Chinese society in the view of the transition from convention to law. Economics and Philosophy (pp. 194-234). Shanghai: Century Press Group, Shanghai Renmin Press.

XIAO, H. (2005, March 31). The Wenzhou logics after the shoes detention event. Southern Weekly, p. C22.

$\mathrm{XU}$, P. (2003). Historical investigation and studying of the economic roles of Japanese government. Beijing: Chinese Social Sciences Press.

XU, Z. (2006, Mar. 9). Solar energy makes new wealthist man and imitators squeeze the industry. Southern Weekly, p. C23.

YANG, B. (1985). The ugly Chinese. Taipei and Beijing: Linbai Press.

YANG, X. K. (2000). The disadvantage of latecomer. The Web of China's Economics Education and Research. Retrieved from http://bbs.cenet.org.cn/html/board835/topic25344.htm

YIN, B. Y. (1993). Why did Korea succeed. Beijing: Wenjin Press.

ZHANG, C. W. (2006, January 26). Price competition in crystal liquid TV, local firms stay aside (Yejing Dianshi Jiage Zhan, Bentu Changshang Yibian Kan). Southern Weekly, p. B15.

ZHANG, L. P. (1993). Confliction and integration of civilizations-study of Japanese modernization. Beijing: Wenjin Press.

ZHANG, Q. J. (2000). The economic consequences of traditional Chinese culture. Journal of Shandong Social Scineces, 6, 78-82.

ZHANG, Q. J. (2005). The significance of the equilibrium between market and religious input-The effects of religious input on economic performance in different religious societies. Journal of Institutional Economic Studies, 6, 85-103.

ZHANG, Q. J. (2006). Strong preference, weak preference and institutional change. Journal of Economists, 3, 89-96.

ZHANG, Y. X. (2005, December 15). National culture studies is popular in Chinese (Guo Ren Xingqi Guoxue Re). People's Daily (Overseas Edition), p. 2.

ZHOU, J. B. (2001). Westernization movement and the early thought of China's modernization. Jinan: Shandong Renmin Press. 